\title{
An analysis of the possibilities of using new types of polymeric inhibitors in the technology of drilling fluids in shale formations
}

The paper presents an overview of the currently used inhibited drilling fluids with the ability to reduce the hydration of the shale. Based on literature data the possibility of using drilling muds in shale formations was analysed. The rest of the article presents the results of research intended to select new chemicals used as inhibitors of the hydration of rocks in drilling muds for drilling in shale. In this study agents such as a new type of polyglycol, an alkoxy derivative of butanol and an amine compound were used. New types of inhibitors were used in the composition of drilling fluids developed for drilling in shale. The carried out investigations of thermal resistance, resistance to pollution with mono- and multivalent ions, and studies on their impact on the disintegration of Miocene shale have shown that the developed muds have suitable technological parameters, are resistant to pollution with bivalent metal ions and temperature, and provide effective protection against Miocene shale hydration up to $100 \%$. The investigations were performed under the Blue Gas project.

Key words: drilling fluid, hydration inhibitors, polyglycol, amine compounds.

\section{Analiza możliwości wykorzystania nowych rodzajów inhibitorów polimerowych w technologii płuczek wiertniczych w formacjach łupkowych}

W artykule przedstawiono przegląd obecnie stosowanych płuczek wiertniczych inhibitowanych wykazujących zdolność ograniczania niekorzystnych zjawisk fizykochemicznych zachodzących w układzie łupek ilasty-płuczka wiertnicza. W oparciu o dane literaturowe przeanalizowano możliwości wykorzystania do wierceń w formacjach łupkowych obecnie stosowanych płuczek inhibitowanych. W dalszej części artykułu przedstawiono wyniki badań mające na celu wytypowanie nowych środków chemicznych spełniających rolę inhibitorów hydratacji skał w płuczkach wiertniczych przeznaczonych do przewiercania skał ilastych. W przeprowadzonych badaniach zostały zastosowane środki takie jak: nowy rodzaj poliglikolu, alkoksylowa pochodna butanolu oraz związek aminowy. Nowe rodzaje inhibitorów znalazły zastosowanie w opracowanych składach płuczek wiertniczych do przewiercania skał ilastych. Przeprowadzone badania odporności termicznej, odporności na skażenie jonami jedno- i wielowartościowymi oraz badania ich wpływu na dezintegrację łupka mioceńskiego wykazały, że opracowane płuczki charakteryzują się odpowiednimi parametrami technologicznymi, są odporne na skażenie jonami metali dwuwartościowych i podwyższoną temperaturę oraz zapewniają skuteczną ochronę łupka mioceńskiego przed hydratacją nawet do wartości bliskich 100\%. Przedstawione badania wykonano w ramach projektu Blue Gas - Polski Gaz Łupkowy.

Słowa kluczowe: płuczka wiertnicza, inhibitory hydratacji skał, poliglikol, związki aminowe. 


\section{Introduction}

The geological-deposit conditions in hydrocarbon extraction from non-conventional deposits indicate the necessity to especially focus on the use of effective systems of rock hydration inhibitors in drilling fluids. Drilling fluids of high degrees of inhibition are now known and successfully used for drilling in conventional deposits. Failure-free quick drilling of a large number of boreholes requires, when designing the drilling fluid composition, drawing attention to the possibility of easy modification of its parameters to adapt them to geological conditions changing during drilling. Ensuring appropriate contact with the deposit zone is possible when opening non-conventional deposits with boreholes which substantially deviate from the perpendicular or horizontal. Because of that, the rheological parameters of the drilling fluid at low shear rates to ensure suspension of borings require particular control, which would substantially contribute to reducing failures related to borings deposition on the borehole bottom $[1,10,13]$.

\section{Drilling fluids used in industrial conditions to drill in clay rocks}

Effective systems of rock hydration inhibitors feature the capability to prevent both the dispersion and swelling of clay minerals contained in rocks. Such agents show various mechanisms of action, and their common characteristic is that they cause physicochemical phenomena resulting in maintaining borehole wall stability. Moreover, the ensuring of appropriate inhibition level prevents damage to the close to borehole zone. Polymer-potassium, glycol, silicate drilling fluids of the so-called triple inhibition system (including HPWBM type drilling fluid), and others are recommended for drilling in clay rocks $[3,4,7,11]$.

The potassium-polymer drilling fluid is a drilling fluid of the so-called 'double inhibition system', in which the basic chemical agents showing the capability to reduce the hydration of clay rocks are potassium chloride as an ion inhibitor, and a high polymer as a polymer inhibitor. Partially hydrolysed polyacryloamide (PHPA) is the most often used polymer inhibitor of clay rocks hydration. This is an anion type polymer, which as a result of the interaction between the positively charged edges of clay parts and the negatively charged polymer carboxyl groups creates a thin coat, which is an obstruction to filtrate migration from the drilling fluid. Such polymers are referred to as encapsulating polymers $[2,3]$.

In certain drilling regions clay rocks exist, especially sensitive to the action of water, for which the use of a cation drilling fluid is recommended, where two cation polymers low and high - are its basic components. The mechanism of the inhibiting action of cation polymers consists in the fact that they bind via electrostatic forces with negatively charge the surface of a clay rock, neutralising its negative charge. Analyses of rock clays dispersion in the cation drilling fluid environment have shown its good inhibiting properties: recoveries of clays after dispergation in a cation drilling fluid reached values close to $100 \%[3,14]$.

Also, glycol-potassium drilling fluid is classified as a drilling fluid of double ion-polymer inhibition. In this drilling fluid the function of a polymer inhibitor is fulfilled by a nonionic polymer - polyglycol, while $\mathrm{KCl}$ is an ionic inhibitor. A clay-free glycol-potassium drilling fluid, because of small damage to reservoir rocks' permeability, may be used to reach productive levels in borings. The inhibiting action of the drilling fluid on clay rocks is explained by the permeation to rock pores of polyglycol drops originating at a higher temperature and mineralisation, and binding polyglycol with clay via hydrogen bonds. Also, $\mathrm{K}^{+}$ions play a significant role in the process of inhibition by polyglycol as a result of synergic interaction with polyglycol $[2,4,5]$.

In turn, when drilling with a silicate drilling fluid, the effective inhibition of clay-shale rocks hydration is obtained, in particular those with microcracks. A water-soluble sodium or potassium silicate, usually referred to as 'water glass', is the basic component of the silicate drilling fluid. The water glass properties depend on its modulus, defined as the mole ratio of silicon dioxide to sodium oxide $\left(\mathrm{n}=\mathrm{SiO}_{2}: \mathrm{Na}_{2} \mathrm{O}\right)$. The mechanism of inhibiting action of the silicate drilling fluid consists in the formation of non-permeable silicic acid gel on the rock surface as a result of drilling fluid contact with the deposit water of low $\mathrm{pH}$, and in silicates' reaction with multivalent ions, resulting in the formation of insoluble sediments $[6,8,12]$. Studies on clay rock dispersion in the environment of silicate drilling fluids developed at the Oil and Gas Institute - National Research Institute and AGH and the Diament company have shown its high effectiveness in rocks hydration inhibition. Recoveries of Eocene shale after dispersion in this drilling fluid environment reached as much as $100 \%$ [9].

A drilling fluid of a high inhibition degree, referred to in the literature as the 'HPWBM' (High Performance Water Based Mud) drilling fluid, contains in its composition a potassium salt and two polymers, i.e. a high polymer used to encapsulate the borehole walls, which, adsorbing on the rock surface forms a membrane (film), limiting the permeation of water into rock formations, and a polymer of low molecular mass (most 
frequently an amine compound) preventing the swelling of clayshale rocks. The inhibition properties of this drilling fluid are compared to an inversion drilling fluid. Moreover, this drilling fluid features appropriate lubricating properties $[3,4,11,15]$.

The choice of appropriate inhibition properties of drilling fluids to drill in clayey shale, which is at the same time a host and reservoir rock, is very important due to such rocks' propensity for water absorption, causing their hydration. As a result on uncontrolled hydration caused by the physicochemical action of the filtrate from the drilling fluid on clay-shale rocks, the crystalline structure of minerals is impaired, and hence the static equilibrium of rocks in the borehole. This leads to reducing the strength of clay rock, increasing its volume and dispersion, and also to the origination of hydration stresses in the rock, which may result in decreasing the borehole diameter, accelerating borehole wall erosion or creating caverns. Hydration of such rocks also results in deterioration of the hydraulic permeability of the rock in the zone close to the borehole, limiting the flow of deposit fluids to the borehole. It is also favourable for the formation of an excess of useless solid phase in the drilling fluid, and thereby to increasing its rheological parameters $[4,14]$.

Also, oil-dispersion drilling fluids may be used to drill in layers of clayey shale. Because of environmental protection, such drilling fluids should be prepared based on a synthetic oil, like fatty acids methyl esters, or polyalphaolefins.

\section{Laboratory investigations}

After carrying out a literature survey, the methodology and scope were determined to select drilling fluids to drill in shale strata. These investigations included the choice of optimum rheological-structural parameters of the drilling fluid based on the determined parameters of drilling, and the properties of drilled strata. Therefore, tests were performed on drilling fluids with double and triple inhibition (ionic inhibitors, polyglycol, water glass, amine compounds, alkoxylated butanol) in the field of selecting the amount and type of effective rock hydration inhibitors with a view to determining their impact on clayey materials. In addition, tests were related to the determination of drilling fluid property changes under borehole-like conditions, for developing a methodology for prepared drilling fluids treatment and controlling their parameters during the borehole drilling.

When selecting new types of rock hydration inhibitors, chemical agents available both from domestic and foreign suppliers were analysed from the point of view of their properties. The properties of new agents acquired for tests show possibilities of their application after modification of drilling fluids' composition as effective inhibitors of rocks hydration. Investigations on choosing rock hydration inhibitors were carried out on drilling fluids containing the minimum amount of loading material due to its small influence on the inhibition properties of drilling fluids.

Polyglycols used in the industry as rock hydration inhibitors mainly include ethylene oxide polymers of varying molecular masses. The glycol drilling fluid developed at the Oil and Gas Institute - National Research Institute at the end of the 1990s contains a copolymer of ethylene oxide and propylene oxide. Polyglycol, used in the current tests, which is also a copolymer of ethylene oxide and propylene oxide, has a higher molecular mass. So there was a need to choose an appropriate type and amount of emulsifier which would ensure dispersion of polyglycol in the drilling fluid. Therefore, tests were carried out on drilling fluids containing various amounts of the new polyglycol type, and of an effective emulsifier. Table 1 specifies the obtained results. Based on the carried out tests, a recipe for a glycol drilling fluid containing a new 2600 polyglycol has been prepared, intended to drill in clay rocks. The performed tests on the rheological parameters of the developed drilling fluid and on thermal resistance, resistance to pollution with mono- and multivalent ions, as well as the results of studies on its impact on Miocene shale disintegration, show a possibility to use it to drill in shale formations. The obtained high values of shale recovery (Table 1, Fig. 1) $P_{1}=88 \div 98 \%$ and $P_{2}=56 \div 72 \%$ prove good protection of clay rocks against hydration by the tested drilling fluids.

Within the Blue Gas project an attempt was also made to develop a new type of triply inhibited drilling fluid (Table 2). To this end a new agent was acquired, being an alkoxy derivative of butanol (hereinafter referred to as 'B 3000'). According to the manufacturer's recommendation this agent works well with PHPA type polymers and $\mathrm{KCl}$ in the drilling fluid composition in the field of rock hydration inhibition. Moreover, agent B 3000 was used in tests on triply inhibited drilling fluids combined with an amine compound and the drilling polyglycol. The amine compound used for tests is a quaternary ammonium salt of alkoxylated acidic amine (in the table marked as amine-IV). The technological parameters of the developed drilling fluids with triple inhibition also show a possibility to use them for drilling in shale formations, while the obtained figures of Miocene shale recovery, both at ambient temperature and at $60^{\circ} \mathrm{C}$, especially the value of $P_{2}$ (Table 2, Fig. 2), prove the high degree of clay-shale rock inhibition.

Also, the drilling fluid composition of triple inhibition has been developed, in which potassium chloride, amine 
Table 1. Properties of drilling fluids with the addition of 2600 polyglycol and emulsifier

\begin{tabular}{|c|c|c|c|c|c|c|c|c|c|c|}
\hline \multirow{2}{*}{ 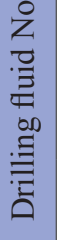 } & \multirow{2}{*}{\multicolumn{2}{|c|}{$\begin{array}{l}\text { Drilling fluid composition } \\
\qquad[\%]\end{array}$}} & \multirow[t]{2}{*}{$\begin{array}{l}\text { Density } \\
\rho \\
{\left[\mathrm{kg} / \mathrm{dm}^{3}\right]}\end{array}$} & \multicolumn{2}{|c|}{$\begin{array}{l}\text { Viscosity } \\
{[\mathrm{mPa} \cdot \mathrm{s}]}\end{array}$} & \multirow{2}{*}{$\begin{array}{c}\text { Yield point } \\
{\left[\mathrm{lb} / 100 \mathrm{ft}^{2} / \mathrm{Pa}\right]}\end{array}$} & \multirow{2}{*}{$\begin{array}{c}\text { Gel } \\
\text { strength } \\
{[\mathrm{Pa}]}\end{array}$} & \multirow[t]{2}{*}{$\begin{array}{l}\text { Filtration } \\
\qquad\left[\mathrm{cm}^{3}\right]\end{array}$} & \multirow[t]{2}{*}{$\mathrm{pH}$} & \multirow{2}{*}{$\begin{array}{c}\text { Dispersion } \\
{[\%]} \\
P_{1} / P_{2}\end{array}$} \\
\hline & & & & $\eta_{p l}$ & $\eta_{s}$ & & & & & \\
\hline 1 & $\begin{array}{l}\text { Biocide } \\
\text { Gelatinised starch } \\
\text { Xanthan resin } \\
\mathrm{KCl} \\
\mathbf{2 6 0 0} \text { Polyglycol } \\
\text { Emulsifier } \\
\text { Carbonate blocking agent }\end{array}$ & $\begin{array}{l}0.1 \\
3.0 \\
0.2 \\
5.0 \\
3.0 \\
1.0 \\
7.0\end{array}$ & 1070 & 20 & 36.0 & $32 / 15.3$ & $4.3 / 6.7$ & 2.0 & 9.2 & $98 / 66$ \\
\hline 2 & $\begin{array}{l}\text { Drilling fluid } 1 \\
+ \text { borings }\end{array}$ & 7.0 & 1110 & 21 & 33.5 & $25 / 12$ & $3.3 / 3.8$ & 1.0 & 8.5 & \\
\hline 3 & $\begin{array}{l}\text { Drilling fluid } 2 \\
+ \text { Xanthan resin }(\Sigma 0.25 \%)\end{array}$ & 0.05 & 1110 & 23 & 38.0 & $30 / 14,4$ & $4.3 / 6.7$ & 1.2 & 8.4 & \\
\hline 4 & $\begin{array}{l}\text { Drilling fluid } 3 \\
+ \text { barite }\end{array}$ & & 1210 & 24 & 38.0 & 28/13.4 & $3.8 / 7.2$ & 0.4 & 8.4 & \\
\hline 5 & $\begin{array}{l}\text { Drilling fluid } 4 \\
\text { temp. } 100^{\circ} \mathrm{C} \\
+\mathrm{NaOH}\end{array}$ & 0.1 & 1210 & 21 & 33.5 & $25 / 12.0$ & $2.9 / 3.8$ & 2.0 & 8.8 & \\
\hline 6 & $\begin{array}{l}\text { Drilling fluid } 5 \\
+\mathrm{CaCl}_{2} \\
+\mathrm{NaOH}\end{array}$ & 1.0 & 1220 & 22 & 33.5 & $23 / 11.0$ & $2.9 / 4.3$ & 1.0 & 9.3 & \\
\hline 7 & $\begin{array}{l}\text { Drilling fluid } 6 \\
+\mathrm{MgCl}_{2}\end{array}$ & 4.0 & 1220 & 22 & 32.5 & $21 / 10.0$ & $2.4 / 3.3$ & 1.0 & 8.7 & \\
\hline 8 & $\begin{array}{l}\text { Biocide } \\
\text { Gelatinised starch } \\
\text { Xanthan resin } \\
\mathrm{KCl} \\
\mathbf{2 6 0 0} \text { Polyglycol } \\
\text { Emulsifier } \\
\text { Carbonate blocking agent }\end{array}$ & $\begin{array}{l}0.1 \\
3.0 \\
0.2 \\
5.0 \\
\mathbf{3 . 0} \\
\mathbf{2 . 0} \\
7.0\end{array}$ & 1070 & 16 & 24.5 & $17 / 8.1$ & $0.96 / 1.9$ & 2.0 & 9.4 & $88 / 56$ \\
\hline 9 & $\begin{array}{l}\text { Drilling fluid } 8 \\
+ \text { borings }\end{array}$ & 7.0 & 1110 & 17 & 27.5 & $21 / 10.0$ & $1.9 / 2.9$ & 1.0 & 8.7 & \\
\hline 10 & $\begin{array}{l}\text { Drilling fluid } 9 \\
+ \text { Xanthan resin }(\Sigma 0.25 \%)\end{array}$ & & 1110 & 18 & 29.5 & 23/11.0 & $1.9 / 3.8$ & 1.0 & 8.6 & \\
\hline 11 & $\begin{array}{l}\text { Drilling fluid } 10 \\
+ \text { barite }\end{array}$ & & 1200 & 20 & 31.0 & $22 / 10.5$ & $1.44 / 3.3$ & 1.0 & 8.5 & \\
\hline 12 & $\begin{array}{l}\text { Drilling fluid } 11 \\
\text { temp. } 100^{\circ} \mathrm{C} \\
+\mathrm{NaOH}\end{array}$ & & 1200 & 21 & 32.5 & $23 / 11.0$ & $2.4 / 4.3$ & 1.0 & 8.9 & \\
\hline 13 & $\begin{array}{l}\text { Drilling fluid } 12 \\
+\mathrm{CaCl}_{2} \\
+\mathrm{NaOH}\end{array}$ & 1.0 & 1220 & 20 & 30.5 & $21 / 10.0$ & $1.44 / 2.4$ & 0.8 & 9.1 & \\
\hline 14 & $\begin{array}{l}\text { Drilling fluid } 13 \\
+\mathrm{MgCl}_{2}\end{array}$ & & 1220 & 21 & 29.5 & $17 / 8.1$ & $1.44 / 2.4$ & 1.0 & 8.8 & \\
\hline 15 & $\begin{array}{l}\text { Biocide } \\
\text { Gelatinised starch } \\
\text { Xanthan resin } \\
\mathrm{KCl} \\
\mathbf{2 6 0 0} \text { Polyglycol } \\
\text { Emulsifier } \\
\text { Carbonate blocking agent }\end{array}$ & $\begin{array}{l}0.1 \\
3.0 \\
0.2 \\
5.0 \\
\mathbf{3 . 0} \\
\mathbf{3 . 0} \\
7.0\end{array}$ & 1070 & 16 & 24.0 & $16 / 7.6$ & $0.96 / 1.9$ & 1.8 & 9.4 & $88 / 72$ \\
\hline
\end{tabular}


ect. Table 1

\begin{tabular}{|c|c|c|c|c|c|c|c|c|c|c|}
\hline \multirow{2}{*}{ 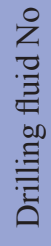 } & \multirow{2}{*}{\multicolumn{2}{|c|}{$\begin{array}{l}\text { Drilling fluid composition } \\
\qquad[\%]\end{array}$}} & \multirow{2}{*}{$\begin{array}{l}\text { Density } \\
\rho \\
{\left[\mathrm{kg} / \mathrm{dm}^{3}\right]}\end{array}$} & \multicolumn{2}{|c|}{$\begin{array}{l}\text { Viscosity } \\
{[\mathrm{mPa} \cdot \mathrm{s}]}\end{array}$} & \multirow{2}{*}{$\begin{array}{c}\text { Yield point } \\
{\left[1 \mathrm{~b} / 100 \mathrm{ft}^{2} / \mathrm{Pa}\right]} \\
\tau_{y}\end{array}$} & \multirow{2}{*}{$\begin{array}{c}\begin{array}{c}\text { Gel } \\
\text { strength } \\
{[\mathrm{Pa}]}\end{array} \\
\mathrm{I} / \mathrm{II}\end{array}$} & \multirow{2}{*}{$\begin{array}{l}\text { Filtration } \\
\qquad\left[\mathrm{cm}^{3}\right]\end{array}$} & \multirow[t]{2}{*}{$\mathrm{pH}$} & \multirow{2}{*}{$\begin{array}{c}\text { Dispersion } \\
{[\%]} \\
P_{1} / P_{2}\end{array}$} \\
\hline & & & & $\eta_{p l}$ & $\eta_{s}$ & & & & & \\
\hline 16 & $\begin{array}{l}\text { Drilling fluid } 15 \\
+ \text { clay (Miocene) }\end{array}$ & & 1110 & 17 & 26.5 & $19 / 9.1$ & $1.44 / 2.4$ & 1.6 & 8.6 & \\
\hline 17 & $\begin{array}{l}\text { Drilling fluid } 16 \\
+ \text { Xanthan resin }(\Sigma 0.25 \%)\end{array}$ & & 1110 & 18 & 29.0 & $22 / 10.5$ & $1.9 / 2.9$ & 1.0 & 8.5 & \\
\hline 18 & $\begin{array}{l}\text { Drilling fluid } 17 \\
+ \text { barite }\end{array}$ & & 1200 & 21 & 31.0 & $20 / 9.58$ & $1.44 / 2.9$ & 1.0 & 8.4 & \\
\hline 19 & $\begin{array}{l}\text { Drilling fluid } 18 \\
\text { temp. } 100^{\circ} \mathrm{C} \\
+\mathrm{NaOH}\end{array}$ & & 1200 & 20 & 31.0 & $22 / 10.5$ & $1.9 / 3.3$ & 0.8 & 8.7 & \\
\hline 20 & $\begin{array}{l}\text { Drilling fluid } 19 \\
+\mathrm{CaCl}_{2} \\
+\mathrm{NaOH}\end{array}$ & 1.0 & 1220 & 20 & 28.5 & $17 / 8.1$ & $1.44 / 2.9$ & 1.0 & 9.0 & \\
\hline 21 & $\begin{array}{l}\text { Drilling fluid } 20 \\
+\mathrm{MgCl}_{2}\end{array}$ & & 1220 & 19 & 27.5 & $17 / 8.1$ & $1.44 / 2.9$ & 1.0 & 8.6 & \\
\hline
\end{tabular}

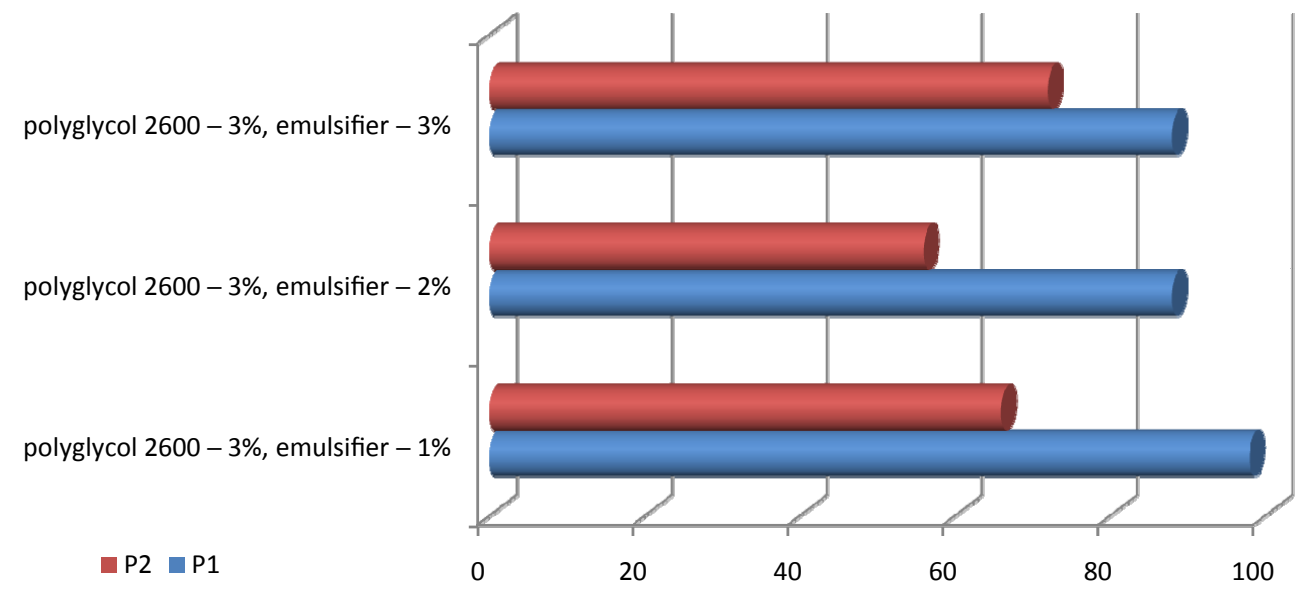

Fig. 1. Results of Miocene shale dispersion analysis in the environment of drilling fluids with 2600 polyglycol and emulsifier addition

compounds (amine-IV) and 2600 polyglycol with emulsifier were used as clay rock hydration inhibitors. The technological parameters of the developed drilling fluid, obtained in tests, show a good thermal resistance, resistance to pollution with mono- and multivalent ions, and show good effectiveness in reducing rock hydration, value $P_{1}$ within the range of $92 \div 100 \%$, value $P_{2}-70 \div 80 \%$. The results of the tests are presented in Table 3 and in Fig. 2.

Performed tests of the rheological properties of drilling fluids using an OFITE HPHT 77 viscometer in the temperature range of $20 \div 120^{\circ} \mathrm{C}$ have confirmed the thermal stability of the developed drilling fluids. In a cycle of heating up to $120^{\circ} \mathrm{C}$ and then cooling down to $20^{\circ} \mathrm{C}$ rheological parameters like plastic viscosity and yield point return to the initial values. Examples of graphs presenting rheological parameter changes for a triply inhibited drilling fluid (inhibitors: potassium chloride, amine compound (amine-IV) and 2600 polyglycol with emulsifier, Table 3, item 1) are presented in Figs. 3 and 4.

The uncertainty of plastic viscosity measurement was estimated at $1 \mathrm{mPa} \cdot \mathrm{s}$, of apparent viscosity at $0.25 \mathrm{mPa} \cdot \mathrm{s}$, of gel strength at $0.5 \mathrm{~Pa}$, and of yield point at $0.75 \mathrm{~Pa}$ based on the accuracy rating of the used viscometer. The density measurement uncertainty was estimated at $5 \mathrm{~kg} / \mathrm{m}^{3}$ based on the accuracy rating of the mud balance. The $\mathrm{pH}$ measurement uncertainty was estimated at 0.05 based on the accuracy rating of the $\mathrm{pH}$ meter. 
Table 2. Properties of drilling fluids with double and triple inhibition with the addition of various inhibitors

\begin{tabular}{|c|c|c|c|c|c|c|c|c|c|c|}
\hline \multirow{2}{*}{ 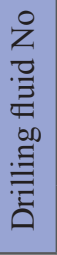 } & \multirow{2}{*}{\multicolumn{2}{|c|}{$\begin{array}{l}\text { Drilling fluid composition } \\
\qquad[\%]\end{array}$}} & \multirow{2}{*}{$\begin{array}{c}\text { Density } \\
\rho \\
{\left[\mathrm{kg} / \mathrm{m}^{3}\right]}\end{array}$} & \multicolumn{2}{|c|}{$\begin{array}{l}\text { Viscosity } \\
{[\mathrm{mPa} \cdot \mathrm{s}]}\end{array}$} & \multirow{2}{*}{$\begin{array}{c}\begin{array}{c}\text { Yield point } \\
{[\mathrm{Pa}]}\end{array} \\
\tau_{y}\end{array}$} & \multirow{2}{*}{$\begin{array}{c}\text { Gel } \\
\text { strength } \\
{[\mathrm{Pa}]} \\
\mathrm{I} / \mathrm{II}\end{array}$} & \multirow[t]{2}{*}{$\begin{array}{l}\text { Filtration } \\
\qquad\left[\mathrm{cm}^{3}\right]\end{array}$} & \multirow{2}{*}{$\begin{array}{c}\text { Dispersion } \\
{[\%]} \\
20^{\circ} \mathrm{C} \\
60^{\circ} \mathrm{C} \\
P_{1} / P_{2}\end{array}$} & \multirow[t]{2}{*}{$\mathrm{pH}$} \\
\hline & & & & $\eta_{p l}$ & $\eta_{s}$ & & & & & \\
\hline 1 & $\begin{array}{l}\text { Biocide } \\
\text { Gelatinised starch } \\
\text { Xanthan resin } \\
\mathrm{KCl} \\
\text { B 3000 } \\
\text { Carbonate blocking agent }\end{array}$ & $\begin{array}{l}0.1 \\
3.0 \\
0.2 \\
5.0 \\
4.0 \\
7.0\end{array}$ & 1070 & 11 & 18.0 & 6.7 & $1 / 1.4$ & 2.0 & $\begin{array}{l}88 / 66 \\
86 / 58\end{array}$ & 9.4 \\
\hline 2 & $\begin{array}{l}\text { Biocide } \\
\text { Gelatinised starch } \\
\text { Xanthan resin } \\
\mathrm{KCl} \\
\text { B 3000 } \\
\text { Amine-IV } \\
\text { Carbonate blocking agent }\end{array}$ & $\begin{array}{l}0.1 \\
3.0 \\
0.2 \\
5.0 \\
4.0 \\
\mathbf{1 . 0} \\
7.0\end{array}$ & 1070 & 14 & 24.0 & 9.6 & $1.9 / 2.4$ & 2.8 & $\begin{array}{l}92 / 78 \\
88 / 68\end{array}$ & 9.4 \\
\hline 3 & $\begin{array}{l}\text { Biocide } \\
\text { Gelatinised starch } \\
\text { Xanthan resin } \\
\mathrm{KCl} \\
\text { B 3000 } \\
\text { Drilling polyglycol } \\
\text { Carbonate blocking agent }\end{array}$ & $\begin{array}{l}0.1 \\
3.0 \\
0.2 \\
5.0 \\
\mathbf{2 . 0} \\
\mathbf{2 . 0} \\
7.0\end{array}$ & 1070 & 14 & 22.5 & 8.1 & $1.4 / 1.9$ & 3.2 & $\begin{array}{l}92 / 70 \\
90 / 60\end{array}$ & 9.4 \\
\hline 4 & $\begin{array}{l}\text { Biocide } \\
\text { Gelatinised starch } \\
\text { Xanthan resin } \\
\mathrm{KCl} \\
\text { B 3000 } \\
\text { PHPA type polymer } \\
\text { Carbonate blocking agent }\end{array}$ & $\begin{array}{l}0.1 \\
3.0 \\
0.2 \\
5.0 \\
\mathbf{4 . 0} \\
\mathbf{0 . 2} \\
7.0\end{array}$ & 1070 & 18 & 30.0 & 11.5 & $1.9 / 2.4$ & 3.2 & $\begin{array}{l}98 / 80 \\
98 / 76\end{array}$ & 9.4 \\
\hline 5 & $\begin{array}{l}\text { Biocide } \\
\text { Gelatinised starch } \\
\text { Xanthan resin } \\
\mathrm{KCl} \\
\mathbf{2 6 0 0} \text { Polyglycol } \\
\text { Sodium silicate } \\
\text { Carbonate blocking agent }\end{array}$ & $\begin{array}{l}0.1 \\
3.0 \\
0.2 \\
5.0 \\
\mathbf{1 . 5} \\
\mathbf{5 . 0} \\
7.0\end{array}$ & 1080 & 15 & 29.5 & 14.4 & $2.9 / 3.9$ & 12.0 & $100 / 78$ & 8 \\
\hline
\end{tabular}

polyglycol $2600-3 \%$, amine-IV $2 \%$, emulsifier - $1 \%$

polyglycol $2600-3 \%$, amine-IV $1 \%$, emulsifier $-1 \%$

polyglycol $2600-1,5 \%$, water glass $-5 \%$

B $3000-4 \%$, PHPA $0,2 \%$

B $3000-2 \%$, drilling polyglycol $-2 \%$

B $3000-4 \%$, amine-IV $1 \%$

B $3000-4 \%$

๑P2 $\square \mathrm{P} 1$

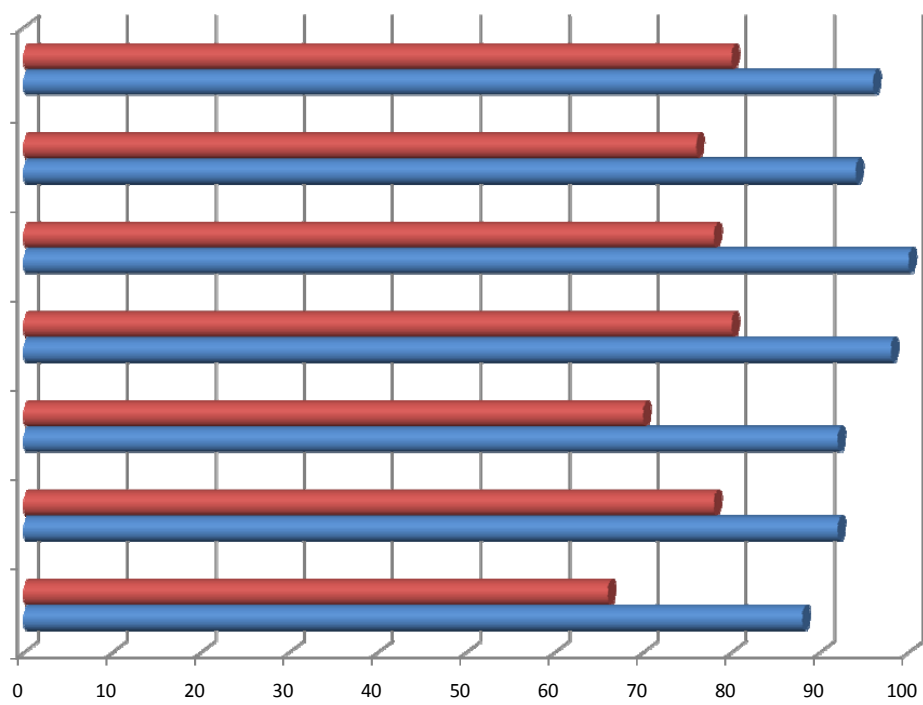

Fig. 2. Results of Miocene shale dispersion analysis in the environment of triply inhibited drilling fluids with the addition of various rock hydration inhibitors 
Table 3. Investigations of chemical resistance for drilling fluids with triple inhibition

\begin{tabular}{|c|c|c|c|c|c|c|c|c|c|c|}
\hline \multirow{2}{*}{ 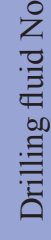 } & \multirow{2}{*}{\multicolumn{2}{|c|}{$\begin{array}{l}\text { Drilling fluid composition } \\
{[[\%]}\end{array}$}} & \multirow[t]{2}{*}{$\begin{array}{l}\text { Density } \\
\rho \\
{\left[\mathrm{kg} / \mathrm{dm}^{3}\right]}\end{array}$} & \multicolumn{2}{|c|}{$\begin{array}{l}\text { Viscosity } \\
{[\mathrm{mPa} \cdot \mathrm{s}]}\end{array}$} & \multirow{2}{*}{$\begin{array}{c}\text { Yield point } \\
{\left[\mathrm{lb} / 100 \mathrm{ft}^{2} / \mathrm{Pa}\right]} \\
\tau_{y}\end{array}$} & \multirow{2}{*}{$\begin{array}{c}\begin{array}{c}\text { Gel } \\
\text { strength } \\
{[\mathrm{Pa}]}\end{array} \\
\mathrm{I} / \mathrm{II}\end{array}$} & \multirow[t]{2}{*}{$\begin{array}{l}\text { Filtration } \\
\qquad\left[\mathrm{cm}^{3}\right]\end{array}$} & \multirow[t]{2}{*}{$\mathrm{pH}$} & \multirow{2}{*}{$\begin{array}{c}\begin{array}{c}\text { Dispersion } \\
{[\%]}\end{array} \\
P_{1} / P_{2}\end{array}$} \\
\hline & & & & $\eta_{p l}$ & $\eta_{s}$ & & & & & \\
\hline 1 & $\begin{array}{l}\text { Biocide } \\
\text { Gelatinised starch } \\
\text { Xanthan resin } \\
\mathrm{KCl} \\
\mathbf{2 6 0 0} \text { Polyglycol } \\
\text { Amine-IV } \\
\text { Emulsifier } \\
\text { Carbonate blocking agent }\end{array}$ & $\begin{array}{l}0.1 \\
3.0 \\
0.2 \\
5.0 \\
\mathbf{3 . 0} \\
\mathbf{1 . 0} \\
\mathbf{1 . 0} \\
7.0\end{array}$ & 1070 & 15 & 23.5 & $17 / 8.1$ & $1.9 / 3.8$ & 2.4 & 9.3 & $94 / 76$ \\
\hline 2 & $\begin{array}{l}\text { Drilling fluid } 1 \\
+ \text { clay (Miocene) }\end{array}$ & 7.0 & 1110 & 18 & 28.5 & $21 / 10.0$ & $2.9 / 3.8$ & 1.8 & 8.8 & \\
\hline 3 & $\begin{array}{l}\text { Drilling fluid } 2 \\
+ \text { barite }\end{array}$ & & 1200 & 21 & 33.0 & $24 / 11.5$ & $2.4 / 5.2$ & 2.0 & 8.7 & \\
\hline 4 & $\begin{array}{l}\text { Drilling fluid } 3 \\
\text { temp. } 100^{\circ} \mathrm{C} \\
+\mathrm{NaOH}\end{array}$ & 0.1 & 1200 & 22 & 35.0 & $26 / 12.4$ & $2.9 / 6.2$ & 1.6 & 8.6 & \\
\hline 5 & $\begin{array}{l}\text { Drilling fluid } 4 \\
+\mathrm{CaCl}_{2} \\
+\mathrm{NaOH}\end{array}$ & 1.0 & 1220 & 21 & 29.0 & $16 / 7.6$ & $1.9 / 4.3$ & 1.0 & 8.6 & \\
\hline 6 & $\begin{array}{l}\text { Drilling fluid } 5 \\
+\mathrm{MgCl}_{2} \\
+\mathrm{NaOH}\end{array}$ & 4.0 & 1220 & 17 & 24.5 & $15 / 7.2$ & $0.96 / 2.4$ & 0.4 & 8.5 & \\
\hline 7 & $\begin{array}{l}\text { Biocide } \\
\text { Gelatinised starch } \\
\text { Xanthan resin } \\
\mathrm{KCl} \\
\mathbf{2 6 0 0} \text { Polyglycol } \\
\text { Amine-IV } \\
\text { Emulsifier } \\
\text { Carbonate blocking agent }\end{array}$ & $\begin{array}{l}0.1 \\
3.0 \\
0.2 \\
5.0 \\
\mathbf{3 . 0} \\
\mathbf{2 . 0} \\
\mathbf{1 . 0} \\
7.0\end{array}$ & 1070 & 14 & 23.0 & $18 / 8.6$ & $2.4 / 3.8$ & 2.4 & 9.3 & $96 / 80$ \\
\hline 8 & $\begin{array}{l}\text { Drilling fluid } 7 \\
+ \text { clay (Miocene) }\end{array}$ & 7.0 & 1110 & 17 & 28.0 & $22 / 10.5$ & $2.9 / 4.3$ & 2.4 & 8.8 & \\
\hline 9 & $\begin{array}{l}\text { Drilling fluid } 8 \\
+ \text { barite }\end{array}$ & & 1200 & 21 & 33.5 & $25 / 12.0$ & $2.9 / 4.8$ & 1.6 & 8.7 & \\
\hline 10 & $\begin{array}{l}\text { Drilling fluid } 9 \\
\text { temp. } 100^{\circ} \mathrm{C} \\
+\mathrm{NaOH}\end{array}$ & & 1200 & 22 & 34.0 & $24 / 11.5$ & $2.9 / 4.8$ & 1.0 & 8.5 & \\
\hline 11 & $\begin{array}{l}\text { Drilling fluid } 10 \\
+\mathrm{CaCl}_{2} \\
+\mathrm{NaOH}\end{array}$ & 1.0 & 1220 & 19 & 26.5 & $15 / 7.2$ & $1.9 / 3.3$ & 0.8 & 8.5 & \\
\hline 12 & $\begin{array}{l}\text { Drilling fluid } 11 \\
+\mathrm{MgCl}_{2} \\
+\mathrm{NaOH}\end{array}$ & & 1220 & 13 & 19.0 & $12 / 5.7$ & $0.96 / 1.9$ & 1.0 & 8.6 & \\
\hline
\end{tabular}




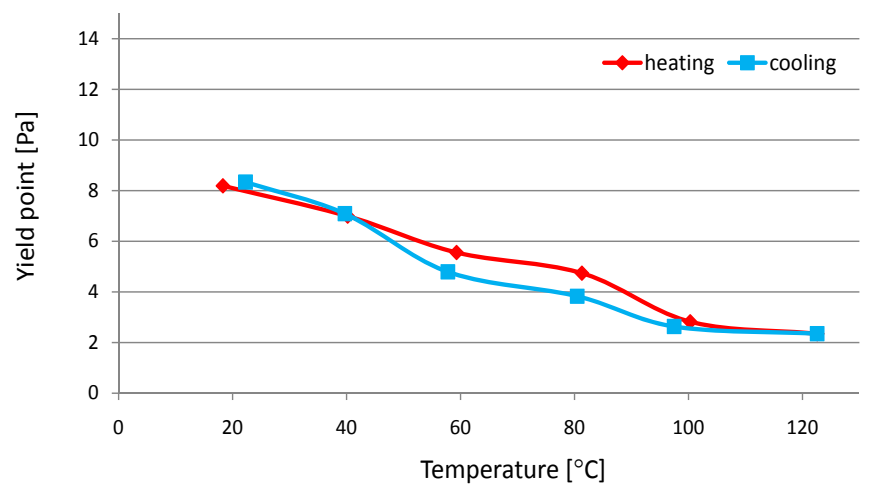

Fig. 3. Changes of yield point for triply inhibited drilling fluid containing inhibitors system: 2600 polyglycol with emulsifier - amine-IV - KCl (drilling fluid 1, Table 3) in the temperature range of $20 \div 120^{\circ} \mathrm{C}$

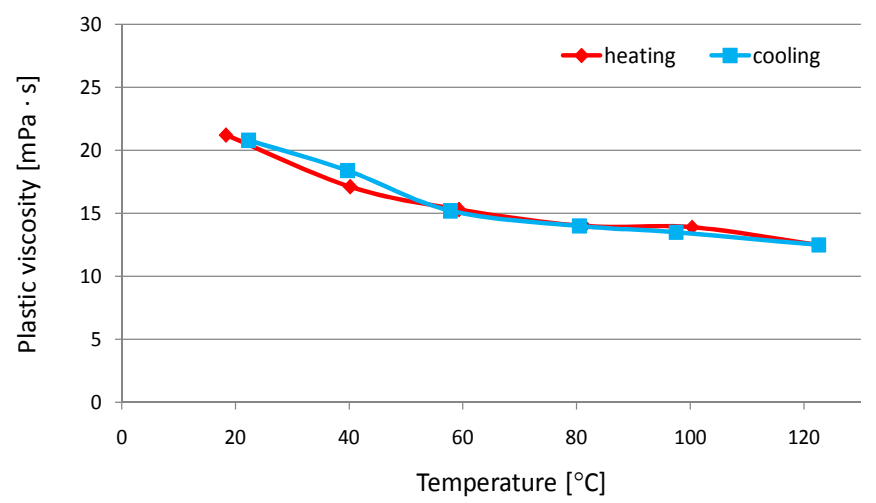

Fig. 4. Changes of plastic viscosity for triply inhibited drilling fluid containing inhibitors system: 2600 polyglycol with emulsifier - amine-IV - $\mathrm{KCl}$ (drilling fluid 1, Table 3) in the temperature range of $20 \div 120^{\circ} \mathrm{C}$

\section{Summary}

The application of appropriate drilling fluid systems is one of the factors resulting in the increased profitability and effectiveness of natural gas extraction from non-conventional deposits. The composition and technological properties of drilling fluids would allow the quick and failure-free carrying out of drilling in accordance with the designed borehole trajectory. Therefore, the effective prevention of shale hydration and the minimisation of drilling fluids' impact on the physicomechanical parameters of those rock becomes an important issue.

Performed laboratory tests allowed the obtaining of new effective rock hydration inhibitors, which were used in developed compositions of drilling fluids for drilling in shale formations. Compositions of doubly and triply inhibited drilling fluids were developed, in which the role of inhibitors is fulfilled by ionic inhibitor $\mathrm{KCl}$, polyglycol, an alkoxy derivative of butanol, water glass and an amine compound (quaternary ammonium salt of alkoxylated acidic amine). The high effectiveness of the chosen inhibitors was confirmed by investigations on clay rocks dispersion in the environment of developed drilling fluids at room temperature and at $60^{\circ} \mathrm{C}$; rock recoveries after dispersion in the drilling fluid $\left(P_{1}\right)$ reach values of $100 \%$ or close to $100 \%$, and after dispersion in water $\left(P_{2}\right) 60 \div 70 \%$.

Tests on the rheological parameters of developed drilling fluids carried out in the temperature range of $20 \div 120^{\circ} \mathrm{C}$ using an OFITE HPHT 77 viscometer have confirmed the thermal stability of the developed drilling fluids in the tested temperature range. The performed tests have shown that the developed drilling fluids feature appropriate rheological parameters, and are resistant to chemical pollution and to elevated temperatures. Based on the carried out tests, it has been found that triply inhibited drilling fluids, and in particular the drilling fluid containing potassium chloride - amine compound (amine-IV) - 2600 polyglycol with emulsifier as inhibitors, and also the drilling fluid in which potassium chloride - alkoxy derivatie of butanol (B 3000) - PHPA were inhibitors have the highest effectiveness in limiting shale disintegration under the impact of drilling fluid action.

Please cite as: Nafta-Gaz 2015, no. 10, pp. 884-892, DOI: 10.18668/NG2015.11.11

Paper submitted to the Editors on 14.09.2015. Approved for publication on 12.10.2015.

The article is the result of research conducted in connection with a project: Optimisation of drilling parameters, including the selection of drilling technology, tools, drilling fluids and cementing of vertical and horizontal boreholes for the extraction of shale gas deposits, co-funded by the National Centre for Research and Development as part of the programme BLUE GAS - POLISH SHALE GAS. Contract No. BG1/OPTIDRILLTEC/13.

\section{Literature}

[1] Beims T.: Next-generation systems optimize WBM performance in horizontal shale plays. American Oil \& Gas Reporter 2010, vol. 53, no. 8, pp. 78-91.

[2] Bielewicz D., Bortel E.: Polimery w technologii pluczek wiertniczych. Uczelniane Wydawnictwa Naukowo-Dydaktyczne, AGH, Kraków 2000.
[3] Blaz S.: Badania laboratoryjne nad opracowaniem skladu pluczki wiertniczej do przewiercania formacji lupkowych. Nafta-Gaz 2013, no. 2, pp. 123-133.

[4] Blaz S.: Nowa generacja pluczek wiertniczych do przewiercania reaktywnych skal ilastych. Nafta-Gaz 2010, no. 5, pp. 390-398. 
[5] Chudoba J., Uliasz M., Raczkowski J., Pawłowski J.: Przemyslowe zastosowanie pluczek glikolowo-potasowych. Konferencja Naukowo-Techniczna GEOPETROL 2000 nt. „Problemy naukowo-badawcze i rozwojowe poszukiwań i eksploatacji złóż gazu ziemnego i ropy naftowej”, Zakopane 25-28 września 2000. Prace IGNiG 2000, no. 110, pp. 483-488.

[6] Chudoba J., Uliasz M., Zima G.: Pluczka wiertnicza z dodatkiem szkla wodnego o roznych modulach. XI Międzynarodowa Konferencja Naukowo-Techniczna nt. „Nowe metody i technologie w geologii naftowej, wiertnictwie, eksploatacji otworowej i gazownictwie", Kraków 29-30 czerwca 2000, vol. I, pp. 59-61.

[7] Deville J. P., Fritz B., Jarrett M.: Development of water-based drilling fluids customized for shale reservoirs. SPE 140868, Texas 2011.

[8] Fritz B., Jarrett M.: Potassium silicate-treated water-based fluid: An effective barrier to instability in the Fayetteville shale. IADC/SPE 151491, California 2012.

[9] Goc A., Bielewicz D.: Zastosowanie pluczki krzemianowej

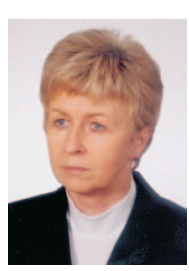

Dr. Eng. Małgorzata ULIASZ PhD.

Head of the Department of Drilling Technology

Oil and Gas Institute - National Research Institute

ul. Lubicz 25 A

31-503 Kraków

E-mail:malgorzata.uliasz@inig.pl

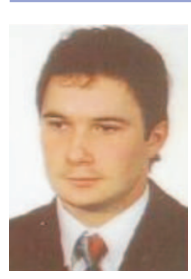

Sławomir BŁAŻ M.Sc. Eng.

Senior Technical Research Specialist

Department of Drilling Technology

Oil and Gas Institute - National Research Institute

ul. Lubicz 25 A

31-503 Kraków

E-mail: slawomir.blaz@inig.pl

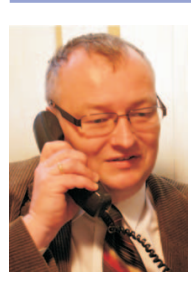

Prof. dr hab. Eng. Rafał WIŚNIOWSKI

Assoc. Professor

AGH University of Science and Technology

Faculty of Drilling, Oil and Gas

al. Mickiewicza 30

30-059 Kraków

E-mail:wisniows@agh.edu.pl w rejonie Kosciana przez PN „Diament”. Wydawnictwa AGH, Wiertnictwo, Nafta, Gaz 2000, vol. 17, pp. 67-72.

[10] Hadro J.: Strategia poszukiwan zloz gazu ziemnego w lupkach. Przegląd Geologiczny 2010, vol. 58, no. 3.

[11] Hoover E., Trenery J.: High-performance WBM optimizes efficiency in demanding Vicksburg wells. American Oil \& Gas Reporter 2008, vol. 29, no. 8, p. 71-74.

[12] Raczkowski J., Chudoba J., Uliasz M.: Nowe rodzaje pluczek wiertniczych wodnodyspersyjnych do przewiercania warstw ilasto-lupkowych. Nafta-Gaz 2000, no. 1, pp. 23-28.

[13] Uliasz M.: Nowe aplikacje w zakresie udostepniania i eksploatacji zloz weglowodorow otworami kierunkowymi i poziomymi. Pluczki wiertnicze $w$ technologii wiercenia otworow kierunkowych i poziomych. Prace INiG 2008, no. 152, pp. 99-148.

[14] Uliasz M.: Wplyw polimerow kationowych na inhibitujace wlasciwosci pluczek wiertniczych. Prace IGNiG 2000, no. 107.

[15] Uliasz M.: Wykorzystanie zwiazkow aminowych w technologii pluczek wiertniczych. Nafta-Gaz 2010, no. 7, pp. 577-585.

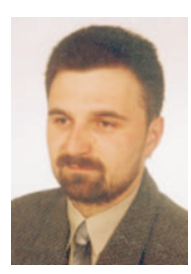

Dr. Eng. Grzegorz ZIMA PhD.

Assistant Professor

Department of Drilling Technology

Oil and Gas Institute - National Research Institute

ul. Lubicz 25 A

31-503 Kraków

E-mail: grzegorz.zima@inig.pl

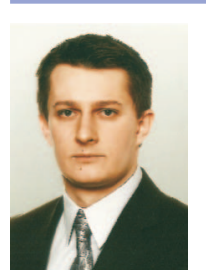

Bartłomiej JASIŃSKI M.Sc. Eng.

Junior scientist

Department of Drilling Technology

Oil and Gas Institute - National Research Institute

ul. Lubicz 25 A

31-503 Kraków

E-mail: bartlomiej.jasinski@inig.pl

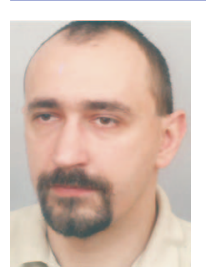

Dr. Sławomir WYSOCKI PhD.

Assistant Professor

Faculty of Drilling, Oil and Gas

University of Mining and Metallurgy. St. Science

and Technology in Krakow

al. Mickiewicza 30, 30-059 Kraków

E-mail:swysocki@agh.edu.pl 